University of New Mexico

UNM Digital Repository

Long Term Ecological Research Network

Long Term Ecological Research (LTER)

7-1990

Long-Term Ecological Research and the Invisible Present

John J. Magnuson

Follow this and additional works at: https://digitalrepository.unm.edu/lter_reports 


\title{
Long-Term Ecological Research and the Invisible Present
}

\author{
Uncovering the processes hidden because they occur slowly or \\ because effects lag years behind causes
}

John J. Magnuson

A

ll of us can sense change-the reddening sky with dawn's new light, the rising strength of lake waves during a thunderstorm, and the changing seasons of plant flowering as temperature and rain affect our landscapes. Some of us see longer-term events and remember that there was less snow last winter or that fishing was better a couple of years ago. But it is the unusual person who senses with any precision changes occurring over decades. At this time scale, we are inclined to think of the world as static, and we typically underestimate the degree of change that does occur. Because we are unable directly to sense slow changes and because we are even more limited in our abilities to interpret their cause-and-effect relations, processes acting over decades are hidden and reside in what I call "the invisible present" (Magnuson et al. 1983).

The invisible present is the time scale within which our responsibilities for planet earth are most evident. Within this time scale, ecosystems change during our lifetimes and the lifetimes of our children and our grandchildren. This is the time scale of acid deposition, the invasion of non-native plants and animals, the introduction of synthetic chemicals, $\mathrm{CO}_{2}$-induced climate warming, and

John J. Magnuson, a fisheries ecologist, is a professor of zoology and is the director of the Center for Limnology at the University of Wisconsin, Madison, WI 53706. (C) 1990 American Institute of Biological Sciences.

\section{In the absence of long- \\ term research, serious misjudgments can \\ occur in attempts \\ to manage \\ the environment}

deforestation. In the absence of the temporal context provided by longterm research, serious misjudgments can occur not only in our attempts to. understand and predict change in the world around us, but also in our attempts to manage our environment. Although serious accidents in an instant of human misjudgment can be envisioned that might cause the end of Spaceship Earth (sensu Fuller 1970), destruction is even more likely to occur at a ponderous pace in the secrecy of the invisible present.

\section{Revealing the invisible present}

Long-term or sustained research can open for view the events of the invisible present, much like time-lapse photography reveals the blooming of a flower or the movement of a snail. A single year's observation of any structure or event, such as the duration of ice cover on Lake Mendota in the winter of 1982-1983 (Figure 1, top), from a long-term perspective is relatively uninteresting in that it provides, in itself, no insight into the long-term behavior of a natural system. Yet when a time series of annual values is opened to 10 years, to 50 years, or to the length of the record-132 yearsthe invisible present is put into context and can be better understood.

With ten years of record, it is apparent that the duration of ice cover in 1983 was 40 days or so shorter than any of the other nine years and far exceeded the typical range of variation. Also, we see that the duration of ice cover varies considerably from year to year. With 50 years of record, it becomes apparent that 1983 and other El Niño years tended to have shorter durations of ice cover (Robertson 1989). Now the phenology of ice cover is linked to a major feature of global climate, the southern ocean oscillation index (Mysak 1986, Quinn et al. 1978). With 132 years of record (Robertson 1989), a general warming trend becomes visible that was invisible with the 10- and 50-year records.

A little ice-age ended in approximately 1890 (Lamb 1977, Wahl and Lawson 1970), as reflected by the decrease in the duration of ice cover. In the most recent years, there is a hint that another warming has begun, perhaps signaling $\mathrm{CO}_{2}$-induced global climate warming (Liss and Crane 1983). The entire time series shows that the 1983 ice cover was the shortest observed in the entire 132 years. Thus each increase in the period of record revealed new insights about the invisible present and made the condition in 1983 more understandable and more interesting.

As with observational studies, field experiments also can be susceptible to 
serious misinterpretation if they are not conducted in the context of long-term ecological research (Tilman 1989). $\mathrm{Ni}$ -
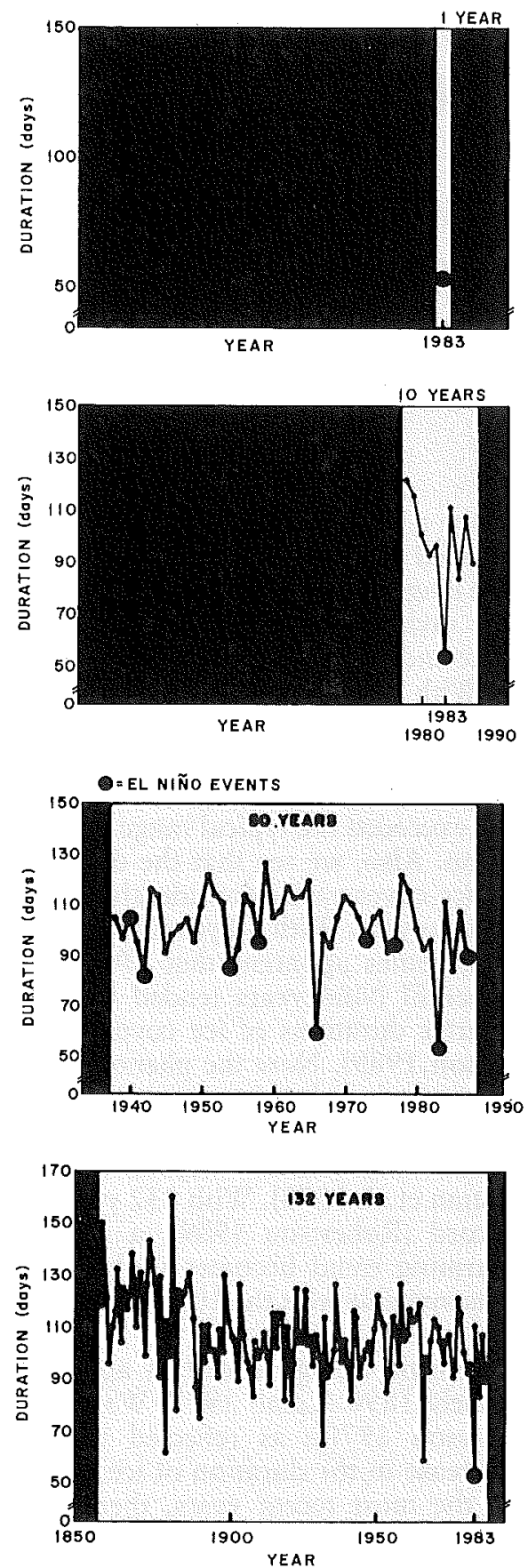

Figure 1. When a time series is opened up, new phenomena become apparent and the present is put into a context that makes it more understandable and more interesting. The duration of ice cover on Lake Mendota, Wisconsin, at Madison, has been recorded, originally by interested citizens beginning in 1855 and now by the state's climatologist, providing the longest limnological and climatological record in the state. The record was analyzed by Dale M. Robertson (1989). trogen addition to plots in an old-field environment at the Cedar Creek Natural History Area site in Minnesota illustrates this point (Figure 2).

If the influence of nitrogen was judged in the first year after fertilization, ecologists might have concluded that fertilization increased perennial ragweed (Ambrosia coronopifolia) and bluegrass (Poa pratensis) and had no influence on blackberry (Rubis sp.). The five-year time series is more revealing; perennial ragweed responded immediately and then dramatically declined to control levels, bluegrass responded more positively in the second year and by the fifth year was significantly less abundant than in control plots, and blackberry showed no change in the first year but had a highly significant increase in abundance by the fifth year (Tilman 1988). Therefore, response to nitrogen fertilization is time dependent. The responses after one, three, or five years are each statistically significant and repeatable, but each differs significantly from the other years. This time series displays features invisible from one- or two-year experiments. Clearly, a one-year experiment, even though its results would be repeatable and statistically significant, does not reflect the total change induced by the fertilization; instead of perennial ragweed and bluegrass as suggested in year one, blackberry dominates by year five.

\section{Long-Term Ecological Research}

Long-Term Ecological Research (LTER) is a program at the National Science Foundation (Brenneman 1989, Callahan 1984, Franklin et al. page 509 this issue, Magnuson and Bowser 1990, Swanson and Franklin 1988) that concentrates on unveiling the invisible present. Researchers at a network of sites (17 in 1990) across the United States focus their research on time scales of years, to decades, to a century, and examine ecological processes over longer periods than possible in most other ecological studies (Figure 3). The researchers also address a wide range of spatial scales-meters to kilometers to crosscontinent intersite comparisons (Swanson and Sparks page 502 this issue).
Funded by the National Science Foundation's Division of Biotic Systems and Resources, the LTER sites include temperate and tropical forests, prairie, desert, alpine and arctic tundra, agricultural fields, lakes, rivers, coastal wetlands, and an estuary. At each site, major questions are addressed related to patterns and controls of primary production, food webs, population abundance and distribution, organic matter accumulation, and biogeochemical cycling, as

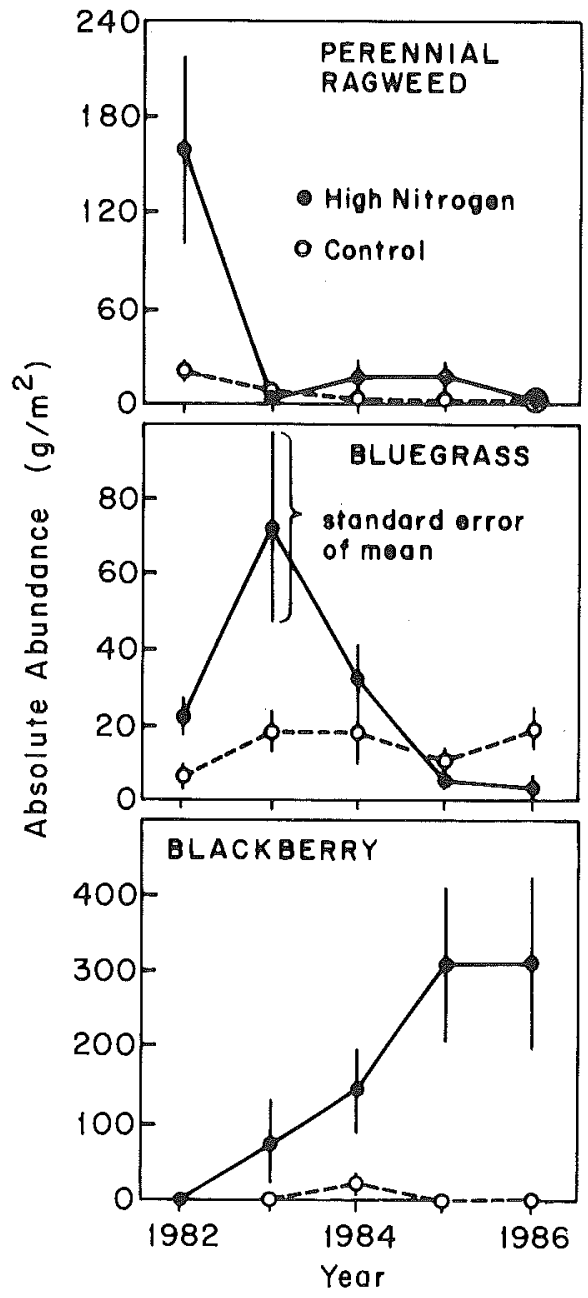

Figure 2. The response of a natural ecological system to a treatment or a disturbance is a time series, much like a successional sequence, rather than a single observation. Nitrogen was added to plots in an old field at the Cedar Creek Natural History Area LTER Site in Minnesota, and other plots were left as controls (Tilman 1987). The response in absolute abundance (means and standard errors) of perennial ragweed (Ambrosia coronopifolia), bluegrass (Poa pratensis), and blackberry (Rubis sp.) are shown from 1982 to 1986. (Figure adapted from Tilman 1989.) 
well as questions related to disturbance frequency and effect. A base of common measurements and questions also lays the groundwork for new analyses and generalizations across different ecosystems relatively unencumbered by the unique character of each ecosystem. In addition, the accumulating record and experience provide a temporal and spatial context for individual researchers needing such a base for their experiments.

LTER sites are regional and national research facilities for long-term or sustained ecological research. Institutions operating LTER sites encourage collaborative research by scientists at other institutions and the use of the sites by visiting investigators. Paleoecology and paleolimnology complement long-term observational study because they provide an even longer term context for interpreting the present. Because such studies have lower temporal, spatial, and biotic resolution than is possible with biological observations and experiments, they in turn are complemented by long-term research. Many important ecological changes and processes are played out over a long time scale, and they are often the ones with human relevance (Likens 1983, 1989).

\section{Long-term lags between cause and effect}

Time lags of longer than a year can exist between cause and effect or until ecological responses to a disturbance permeate natural systems. These time lags occur for many reasons: certain biological and physical processes simply take time, biological relicts persist even after conditions change, movements across the landscape take time, the simultaneous occurrence of two or more necessary conditions for an event or process to occur can be rare, and a chain of events accumulates the lags between cause-and-effect events. Each of these reasons for time lags will be illustrated with examples from LTER sites.

Processes taking time. The accumulation of biomass is a good example of a process that simply takes time. The example for a cohort of trees is the same as for a year-class of fish or for any population of organisms that live a number of years and whose biomass

TIME SCALES

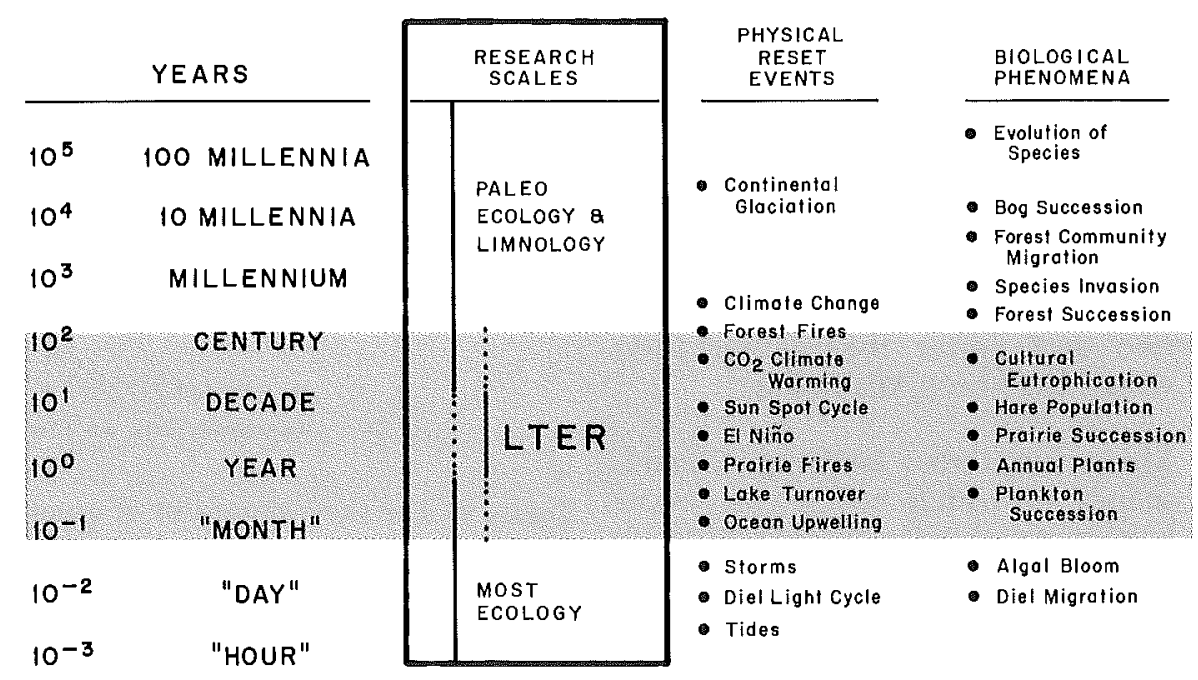

Figure 3. The Long-Term Ecological Research program supported by the National Science Foundation focuses on time scales of years to decades to a century in a major effort to understand ecological structure and function hidden in the invisible present. Time scales relevant to various physical events and biological phenomena are taken from sources including Delcourt et al. (1983), Haury et al. (1978), and Stommel $(1963,1965)$.

does not die back each year. After fish hatch or trees germinate, annual mortalities reduce the total number left in the cohort, but individuals grow larger. The accumulated biomass of the cohort reaches a maximum in the year when the product of the number of organisms still living and their mean body mass is greatest (Beverton and Holt 1957, Pitcher and Hart 1982 for fish). Before the maximum, there are many trees but they are small; after the maximum, the trees are large but are few in number. The time lag between the year when a cohort is formed and when it reaches maximum biomass depends on the mortality and the growth rates of organisms in that particular population; for many fish in freshwater lakes, the time lag is two to four years, but for long-lived trees it may be 200 years or longer.

Biological relicts. A period of successful tree reproduction can produce a forest that may persist into a future that changing conditions have made unsuitable for reproduction. The treeline at the Niwot Ridge/Green Valley Lakes LTER Site in the Rocky Mountains of Colorado has been considered to be a relict treeline, established in the more favorable climate of the altithermal period approximately
4000 years ago (Ives 1978, Ives and Hansen-Bristow 1983, Nichols 1982). Some evidence for this hypothesis is provided by a 1905 burn at the Niwot treeline, where more than 80 years later, the forest shows few signs of recovery. This interpretation is controversial, and Shankman (1984) has projected from seedling and sapling establishment that recovery will yet occur given sufficient time in the absence of disturbance.

Relict biota also persist into the future after conditions have changed over time scales of only a few years. The extensive meadows dominated by the sedge Kobresia on the Niwot Ridge are thought, on the basis of their soil characteristics, to have been in place for centuries. Kobresia prefers sites free of snow in winter; it rarely reproduces sexually on Niwot Ridge but instead maintains itself through vegetative tillering. Pat Webber and his students (Emerick 1976, Keigley 1987, Webber et al. 1976) assessed the resistance of the Kobresia community to environmental change by increasing snowpack with snow fences. In the first two years after greater snowpack, the plant produced more leaves and appeared to be vigorous. The plant apparently reallocated its resources to stature rather than to vegetative reproduction when 
the snowpack was present. But the snowpack prevented the generation of new shoots, and within five years Kobresia was sparse and by ten years had completely disappeared. A time lag, linked causally to the biology of this particular species, is evident in the disappearance of Kobresia; again, as with Tilman's fertilization experiments, a conclusion made in the first two years after the manipulation would have been misleading.

Movement across landscapes. Landscapes in which ecosystems occur have spatial dimensions that influence the temporal ones. Movement of water, materials, and organisms takes time and introduces lags into ecosystem changes. Classic examples are the time for dispersal of exotic plants and animals across the landscape. The European starling (Sturnus vulgaris) dispersed from the New York City area in 1896 to western New Jersey by 1908 and to western Ohio by 1926 (Elton 1958). The sea lamprey (Petromyzon marinus) spread from Lake Ontario after the Welland Canal was built in 1829 into Lake Erie by 1932 (Pearce et al. 1980) and into Lakes Huron, Michigan, and Superior by the late 1930s (Smith and Tibbles 1980). The Asiatic clam (Corbicula fluminea Philippi) was first observed in the Columbia River in 1938; by 1960 it had reached southern Illinois and, by 1975 , southern Wisconsin via dispersal up the Mississippi River (Thompson and Sparks 1977). The Asiatic clam is thought to be inducing ecological changes in the rivers of North America after a time lag of 50 years. ${ }^{1}$

Groundwater movement is slow at the North Temperate Lake LTER Site in Wisconsin, not at all like the rushing streams in more erodible landscapes. The study lakes are arranged along a topographic gradient, and groundwater takes approximately three years to flow from the uppermost, rainwater-dominated lake to the next lower lake only $100 \mathrm{~m}$ downslope. A surface stream would take only minutes. The slow movement of water through the sandy till increases the dissolution of ions, and

${ }^{1}$ R. Sparks, 1989, personal communication. Forbes Biological Station of the Illinois Natural History Survey, Havana, IL.

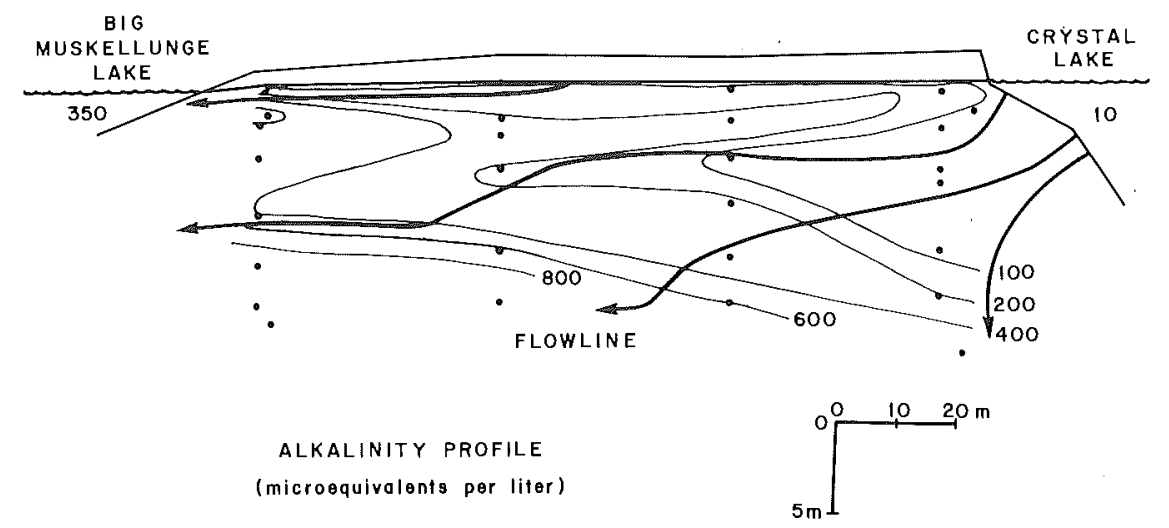

Figure 4. The slow movement of groundwater across the landscape allows time for chemical reactions to increase the alkalinity of the water entering the lower lake at the North Temperate Lake LTER Site in Wisconsin (adapted from Kenoyer 1986). Far more acid buffering capacity is acquired from the till, which is low in carbonates, than would have been expected if flows were faster.

the alkalinity of the water increases dramatically before entering the lower lake (Kenoyer 1986; Figure 4). Owing to this slow movement of groundwater down the landscape from lake to lake, each lake successively lower in the flow system has a higher alkalinity and concentration of solutes. Some of the groundwater now entering the lakes low in the landscape may have been in the flow system 100 years or more and could

be, in part, a product of conditions present before the region was logged and burned near the turn of the century.

Rare coincidence. Time lags can occur because a process requires the coincidence of two or more lowprobability events; in some cases, many years may pass before the events occur together. In the shortgrass steppe at the Central Plains

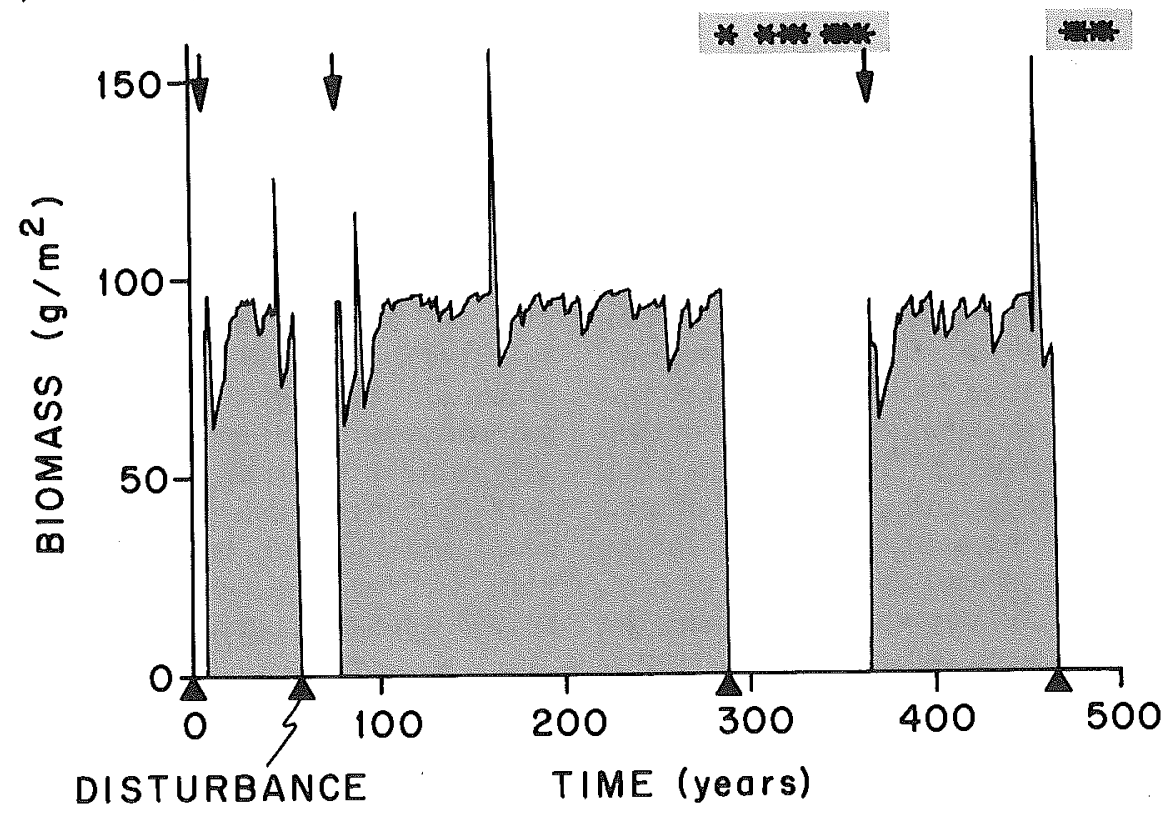

Figure 5. Time lags after a disturbance on the shortgrass steppe occur because the simultaneous occurrence of the events required for reestablishment of the dominant grass (i.e., viable seeds and adequate soil water) is rare. In this simulation by Coffin and Lauenroth (1990), the disturbances that eliminate the blue grama (Bouteloua gracilis) are indicated by four triangles on the $\mathrm{x}$-axis, the asterisks indicate the years after a disturbance when suitable microenvironmental conditions were present but viable seeds were not, and the arrows indicate the first year after a disturbance when both seeds and adequate soil water were present. 
Experimental Range LTER Site in Colorado, plant communities are dominated by a perennial grass, blue grama (Bouteloua gracilis). Disturbances in the shortgrass steppe occur over many spatial and temporal scales, but a particular pair of conditions must occur before blue grama can recover.

Establishment of seedlings requires that viable seeds and adequate soil moisture be present. Both conditions are rare in these semiarid grasslands; viable seeds are produced approximately every seven years and appropriate soil moisture approximately every eight years. The two conditions are independent. Debra P. Coffin and William K. Lauenroth of Colorado State University devised a model to simulate the long-term changes of blue grama on small patches over 500 years (Coffin and Lauenroth 1990; Figure 5).

During the 500-year simulation, the plot was disturbed four times by cattle fecal pats that killed all the blue grama. Fecal pats are the most frequent small-scale disturbance in shortgrass plant communities grazed by domestic cattle and serve as a model of larger scale disturbances such as plowing. The time lags that resulted were, in sequence, approximately 10, 20,80, and, at the end of the record, at least 35 years. This model provides some insight as to why larger sections of the shortgrass steppe that were disturbed by plowing 50 to 100 years ago have not yet recovered.

Chains of events. Time lags also are generated because a cause-and-effect chain of events accumulates the lags from each link in the chain. Changes in water clarity provide a good example (Figure 6). In Crystal Lake, at the North Temperate Lake LTER Site operated by the University of Wisconsin-Madison, we observed a decrease in water clarity over a three-year period from approximately $11 \mathrm{~m}$ to $6 \mathrm{~m}$ in $1984 .^{2}$

This change was initiated by the formation of strong year-classes of yellow perch (Perca flavescens), two

${ }^{2}$ J. J. Magnuson, M. P. Anderson, D. E. Armstrong, C. J. Bowser, T. M. Frost, and T. K. Kratz, 1990, abstract submitted for INTECOL meeting, Yokohama, Japan. and three years before the lowest water clarity was observed. When the perch reached maximal biomass and moved into the open water, they preyed on and reduced the abundance of the microscopic herbivores that eat the planktonic algae. The perchinduced reduction in herbivores lessened grazing pressure on the midwater algae, and these algae increased in abundance. With more algae in the water column, light penetration was reduced and water clarity declined dramatically. As the perch year-classes aged, their biomass and numbers declined and the changes reversed.

Most of this two- to three-year lag resulted from the time it takes for a year-class of fish to obtain maximal biomass. It is at the age of maximal biomass that the perch exerted the

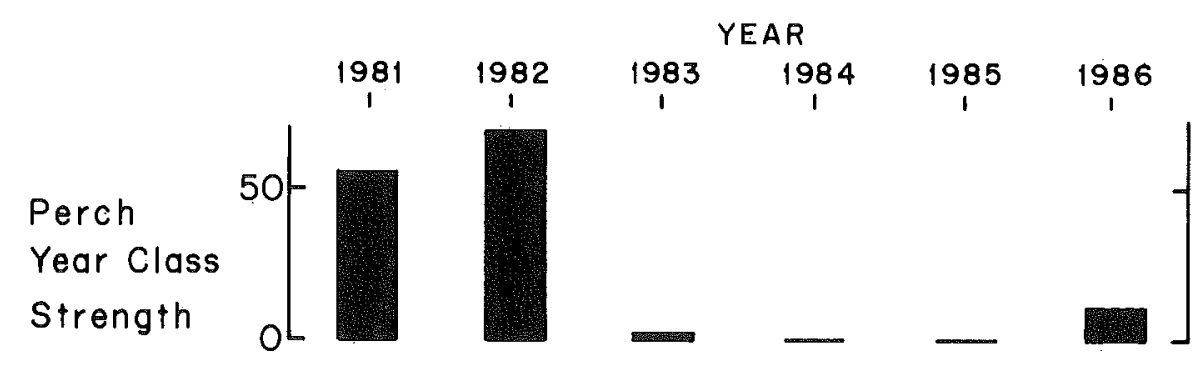

greatest grazing pressure on their prey. These changes were not unexpected (Brooks and Dodson 1965, Carpenter 1988, Carpenter et al. 1985, Henrikson et al. 1980, Hrbacek 1958, Hrbacek et al. 1961, Northcote 1988), but we were surprised by their magnitude.

Earlier, Joan Baker and I (Baker and Magnuson 1976) had observed a decrease in water clarity of Crystal Lake from the early measurements by E. A. Birge and C. Juday in the 1930's and by Baker in 1973. We had concluded that a gradual change over 40 years had occurred owing to changes in human use. It now appears that a much more rapid oscillation in water clarity occurs due to the formation of strong year-classes of perch every few years. Again Baker's short-term re-
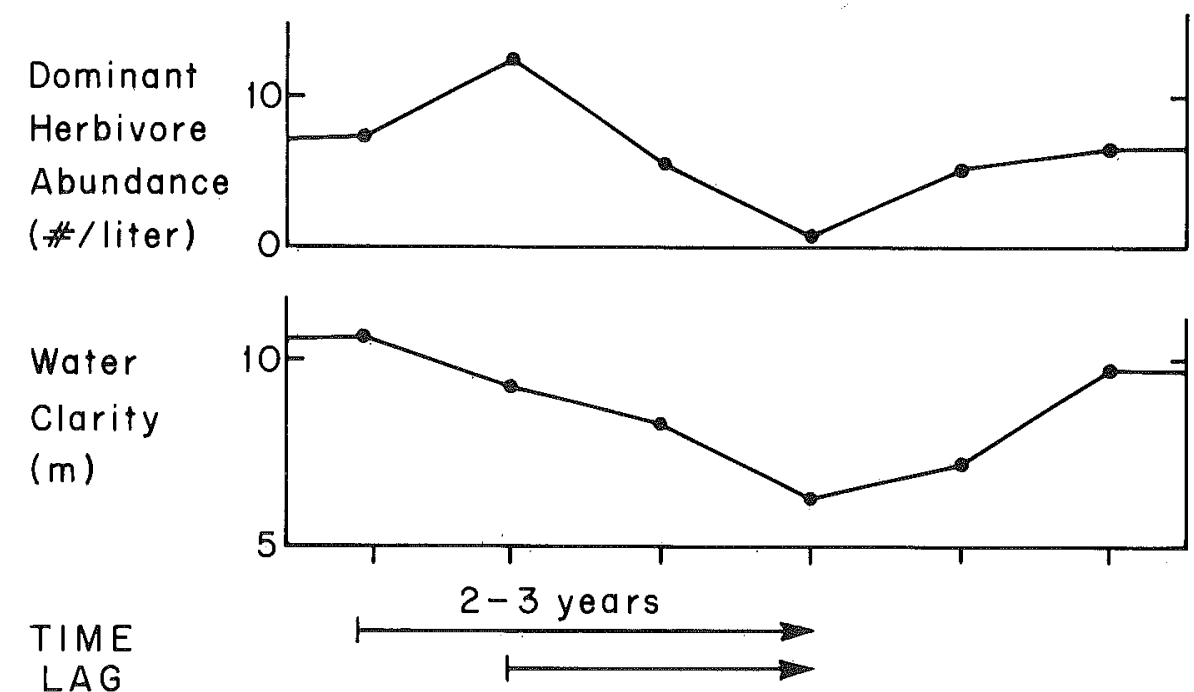

Figure 6. Time lags from a chain reaction in a food web occur because a fish year-class takes several years to reach maximum biomass and thus exert maximal influence on its prey populations. Abundant perch reduce the abundance of herbivorous zooplankton, causing the algae to thrive, in turn decreasing water clarity. 
search, with only one recent year for comparison, did not penetrate the realm of the invisible present.

\section{Conclusions}

The natural world is dynamic, not static, and the older each of us gets, the more apparent is this truth. Time lags in ecological systems are the rule; they separate cause and effect to confuse our interpretation of the natural world, which can appear fickle and unsettled. Increasingly long records of ecosystem structure and process and long-term experiments expose new phenomena and allow greater understanding. The Long-Term Ecological Research Program formalizes this human experience. Such knowledge is sure to help us in facing the problems ahead. Our lack of understanding of events and processes in the time scale of decades has been and will in the future be costly to human society. Operating Space Ship Earth blind to the invisible present is unacceptable.

The invisible present is beginning to be penetrated by researchers and agencies with an increasing awareness of the importance of serious and coordinated research at the time scales of years to decades. LTER is the most extensive.

\section{Acknowledgments}

I thank the National Science Foundation for having the leadership and the insight to establish a program for a network of Long-Term Ecological Research Sites. I thank Patrick J. Webber (Niwot Ridge/Green Valley Lakes LTER Site), who made unpublished materials available for this paper. I thank Donald E. Chandler, Cheryl M. Hughes, and Mary L. Smith of the University of Wisconsin in Madison for preparation of the figures and text. This article was based on a talk presented at a 6 November 1987 briefing at the $\mathrm{Na}$ tional Science Foundation in Washington, DC, and in the LTER Symposium at the Ecological Society of America meeting in August 1988 in Davis, CA.

\section{References cited}

Baker, J., and J. J. Magnuson. 1976. Limnological responses of Crystal Lake (Vilas County,
Wisconsin) to intensive recreational use, 1924-1973. Trans. Wis. Acad. Sci. Arts Lett. 64: 47-61.

Beverton, R. H. J., and S. J. Holt. 1957. On the Dynamics of Exploited Fish Populations. Fishery Investigations. Series II, vol. XIX. Ministry of Agriculture, Fisheries and Food, Her Majesty's Stationery Office, London.

Brenneman, J., ed. 1989. Long Term Ecological Research in the United States: A Network of Sites 1989. 5th ed. Long-Term Ecological Research Network, Forest Science Department, Oregon State University, Corvallis, OR.

Brooks, J. L., and S. I. Dodson. 1965. Predation, body size, and composition of plankton. Science 150: 28-35.

Callahan, J. T. 1984. Long-term ecological research. BioScience 34: 363-367.

Carpenter, S. R. 1988. Transmission of variance through lake food webs. Pages 119-135 in S. R. Carpenter, ed. Complex Interactions in Lake Communities. Springer-Verlag, New York.

Carpenter, S. R., J. F. Kitchell, and J. R. Hodgson. 1985. Cascading trophic interactions and lake productivity. BioScience 35: 634 639.

Coffin, D. P., and W. K. Lauenroth. 1990. A gap dynamics simulation model of succession in a semiarid grassland. Ecol. Model. 49: 229-266.

Delcourt, H. R., P. A. Delcourt, and T. Webb III. 1983. Dynamic plant ecology: the spectrum of vegetational change in space and time. Quaternary Science Reviews 1: 153 175.

Elton, C. S. 1958. The Ecology of Invasions by Animals and Plants. Methuen and Co., London.

Emerick, J. C. 1976. Effects of artificially increased winter snow cover on plant canopy architecture and primary production in selected areas of the Colorado alpine tundra. Ph.D. dissertation, University of Colorado, Boulder.

Franklin, J. F., C. S. Bledsoe, and J. T. Callahan. 1990. Contributions of the Long-Term Ecological Research Program. BioScience 40: 509-523.

Fuller, R. B. 1970. Operating Manual for Spaceship Earth. Touchstone, New York.

Haury, L. R., J. A. McGowan, and P. H. Weibe. 1978. Patterns and processes in the time-space scales of plankton distributions. Pages 277-328 in J. H. Steele, ed. Spatial Pattern in Plankton Communities. NATO Conference Series IV: Marine Sciences 3. Plenum, New York.

Henrikson, L. H., G. Nyman, H. G. Oscarson, and J. E. Stenson. 1980. Trophic changes without changes in external nutrient loading. Hydrobiologia 68: 257-263.

Hrbacek, J. 1958. Density of the fish population as a factor influencing the distribution and speciation of the species in the genus Daphnia. Pages 794-795 in Proceedings of the XVth International Congress of Zoology. Section X, Paper 27.

Hrbacek, J., M. Dvorakova, V. Korinek, and L. Prochazkova. 1961. Demonstration of the effect of the fish stock on the species composition of zooplankton and the intensity of metabolism of the whole plankton association. Verh. Int. Ver. Limnol. 14: 192-195.
Ives, J. D. 1978. Remarks on the stability of timberline. Pages 313-317 in C. Troll and W. Lauer, eds. Geoecological Relations between the Southern Temperate Zone and the Tropical High Mountains. Erdwissenschaftliche Forschung. Franz Steiner, Wiesbaaden, FRG.

Ives, J. D., and K. J. Hansen-Bristow. 1983. Stability and instability of natural and modified upper timberline landscapes in the Colorado Rocky Mountains, U.S.A. Mountain Research and Development 3: 149-155.

Keigley, R. B. 1987. Effect of experimental treatments on Kobresia myosuroides with implications for the potential effect of acid deposition. Ph.D. dissertation, University of Colorado, Boulder.

Kenoyer, G. J. 1986. Evolution of groundwater chemistry and flow in a sandy aquifer in northern Wisconsin. Ph.D. dissertation, University of Wisconsin-Madison.

Lamb, H. H. 1977. Climate: Present, Past, and Future, vol. II. Climatic History and the Future. Methuen and Co., New York.

Likens, G. E. 1983. A priority for ecologists. Bulletin of the Ecological Society of America 64: 234-243.

1989. Long-Term Studies in Ecology: Approaches and Alternatives. SpringerVerlag, New York.

Liss, P. S., and A. J. Crane. 1983. Man-Made Carbon Dioxide and Climatic Change-A Review of Scientific Problems. Geo Books, Norwich, England.

Magnuson, J. J., and C. J. Bowser. 1990. A network for long-term ecological research in the United States. Freshwater Biol. 23: 137143.

Magnuson, J. J., C. J. Bowser, and A. L. Beckel. 1983. The invisible present: long term ecological research on lakes. $L$ or $S$ Magazine, University of Wisconsin, Madison Fall 1983: 3-6.

Mysak, L. A. 1986. El Niño, interannual variability and fisheries in the northeast Pacific Ocean. Can. J. Fish. Aquat. Sci. 43: 464 497.

Nichols, H. 1982. Review of the late Quaternary history of vegetation and climate in the mountains of Colorado. Pages 27-33 in J. C. Halfpenny, ed. Ecological Studies in the Colorado Alpine: A Festschrift for John W. Marr. Occasional Paper 37, Institute of Arctic and Alpine Research, University of Colorado, Boulder.

Northcote, T. G. 1988. Fish in the structure and function of freshwater ecosystems; a "top-down" view. Can. J. Fish. Aquat. Sci. 45: 361-379.

Pearce, W. A., R. A. Braem, S. M. Dustin, and J. J. Tibbles. 1980. Sea lamprey (Petromyzon marinus) in the lower Great Lakes. Can. J. Fish. Aquat. Sci. 37: 1802-1810.

Pitcher, T. J., and P. B. Hart. 1982. Fisheries Ecology. AVI Publ., Westport, CT.

Quinn, W. H., D. O. Zopf, K. S. Short, and R. T. W. Kuo Yang. 1978. Historical trends and the statistics of the southern oscillation, El Niño, and Indonesian droughts. Fish. Bull. 76: 663-677.

Robertson, D. M. 1989. The use of lake water temperature and ice cover as climatic indicators. Ph.D. dissertation, University of Wisconsin, Madison.

Shankman, D. 1984. Tree generation following 
fire as evidence of timberline stability in the Colorado Front Range, U.S.A. Arct. Alp. Res. 16: 413-417.

Smith, B. R., and J. J. Tibbles. 1980. Sea lamprey (Petromyzon marinus) in Lakes Huron, Michigan and Superior: history of invasion and control, 1936-78. Can. J. Fish. Aquat. Sci. 37: 1780-1801.

Stommel, H. 1963. Varieties of oceanographic experience. Science 139: 572-576.

.1965. Some thoughts about planning the Kuroshio survey. In Proceedings of a Symposium on the Kuroshio. Tokyo, Japan. 29 October 1963. Oceanographic Society of Japan and UNESCO.

Swanson, F. J., and J. F. Franklin. 1988. The Long-Term Ecological Research Program. EOS: Transactions of the American Geophysical Union 69(3): 34, 36, 46.

Swanson, F. J., and R. E. Sparks. 1990. Longterm ecological research and the invisible place. BioScience 40: 502-508.

Thompson, C. M., and R. E. Sparks. 1977. The Asiatic clam, Corbicula manilensis in the Illinois River. Nautilus 91: 34-36.

Tilman, D. 1987. Secondary succession and the pattern of plant dominance along experimental nitrogen gradients. Ecol. Monogr. 57: $189-214$

. 1988. Plant Strategies and the Dynamics and Structure of Plant Communities. Princeton University Press, Princeton, New Jersey.

1989. Ecological experimentation: strengths and perceptual problems. Pages 136-157 in G. Likens, ed. Long-Term Studies in Ecology. Springer-Verlag, New York.

Wahl, E. W., and T. L. Lawson. 1970. The climate of the midnineteenth century United States compared to the current normals. Monthly Weather Review 98: 259-265.

Webber, P. J., J. C. Emerick, D. C. Ebert May, and V. Komarkova. 1976. The impact of increased snowfall on alpine vegetation. Pages 201-264 in H. W. Steinhoff and J. D. Ives, eds. Ecological Impacts of Snowpack Augmentation in the San Juan Mountains, Colorado. Final Report, San Juan Ecology Project, Colorado State University Publ., Fort Collins.

\section{Call for Nominees for the 1991} AIBS Distinguished Service Award

Since 1972 the AIBS Distinguished Service Award has been presented to individuals who have contributed significantly in the service of biology. The principal criteria for this award are that the recipients shall have made an outstanding contribution toward:

- advancing and integrating the biological disciplines,

- applying biological knowledge to the solution of world problems, arid

- introducing pertinent biological considerations that improve public policy and planning.

Emphasis is placed on distinguished service. Scientific discovery per se is not included as a criterion for this award, although some nominees will carry this distinction as well.

Previous recipients of the award have been:

- 1972-Harve Carlson, George Miller, Detlev Bronk

- 1973-Theodore Dobzhansky, Rene Dubos

- 1974-James G. Horsfall

- 1975-W. Frank Blair, Theodore Cooper

- 1976-Paul B. Sears, Edward O. Wilson

- 1977-Paul J. Kramer, Elvin C. Stakman, William C. Steere

- 1978-Eugene P. Odum, Howard T. Odum, George Gaylord Simpson

- 1979-Theodore C. Byerly, H. C. Chiang, Lee M. Talbot

- 1980-Arthur D. Hasler, A. Starker Leopold, Ruth Patrick

- 1981-Peter H. Raven

- 1982-George M. Woodwell

- 1983-Karl Maramorosch

- 1984-Arnold B. Grobman

- 1985-Sayed Z. El-Sayed

- 1986-Garrett Hardin

- 1987-Perry L. Adkisson

- 1988-Donald E. Stone

- 1989-Alfred E. Harper

- 1990-Gene E. Likens

AIBS members are invited to submit nominations for this award, which will be presented at the 1991 Annual AIBS Meeting, San Antonio Convention Center, San Antonio, Texas. Each nomination must be accompanied by a complete curriculum vitae and a statement of the individual's service to the biology profession. In particular, the supporting statement should highlight the nominee's accomplishments in each of the three award criteria given above. Nominators should note that traditional academic vitae often omit contributions to public affairs. As this area is considered equally important in the overall consideration, care should be taken to bring out the nominee's relevant accomplishments. Since 1981, recipients have been limited to single individuals, but nomiriations will remain active for three consecutive years, e.g., for the 1991, 1992 and 1993 awards.

Send nominations (with biographies) to the AIBS Executive Director, 73011 th Street, NW, Washington, DC 20001-4521, by 1 October 1990. 


\title{
Long-Term Ecological Research and the Invisible Place
}

\section{The local to global spatial scales of the Long-Term Ecological Research Program}

\author{
Frederick J. Swanson and Richard E. Sparks
}

$\mathrm{T}$ he distinctive feature of the National Science Foundation's Long-Term Ecological Research (LTER) Program has been the opportunity to examine ecosystem behavior on longer time scales than traditionally emphasized in ecological research (Callahan 1984, Franklin et al. page 509 this issue, Magnuson page 495 this issue, Magnuson et. al. in press, Swanson and Franklin 1988). As Magnuson has argued, lack of historical perspective can place short-term studies in the "invisible present," where a lack of temporal perspective can produce misleading conclusions. Similarly, the broad significance of research results from a particular site is difficult to interpret if the site's context in space (e.g., location within region-scale variation in disturbance regime and temperature-moisture conditions) is not understood. In this sense, an isolated research site may reside in an

Frederick J. Swanson is a principal investigator in the Andrews LTER program, a research geologist and project leader with the USDA Forest Service, Pacific Northwest Research Station, and a professor in the Departments of Forest Science and Geosciences, Oregon State University, Corvallis, OR 97331. His primary research interests concern the roles of landforms and geological processes in ecosystems. Richard E. Sparks was a principal investigator in the Illinois-Mississippi River LTER program (1982-1989) and is an aquatic ecologist with the Illinois Natural History Survey's River Research Laboratory. His primary research interests concern the factors controlling productivity in large, floodplain rivers.

\section{Significance of research results is difficult to interpret if a site's context in space is not understood}

"invisible place" where the significance of results is unclear.

As LTER research addresses longer time scales, it has been natural to also confront greater spatial scales (Delcourt et al. 1983). For example, vegetation change at a site over a few years involves processes such as competition among neighboring individual plants. Vegetation change at the same site, but on time scales of centuries and millennia, also involves species migration on broader spatial scales.

Consideration of broader spatial scales in LTER research is fostered by: emergence of critical, large-scale questions concerning ecological effects of global climate change and land use at landscape and regional scales; opportunity to compare ecosystem properties across the continent-spanning LTER system of sites; and development of regional-scale databases and modeling efforts using LTER sites as focal points (Gosz and Sharpe 1989). These factors have resulted in studies within the LTER network at a series of spatial scales. The intent of such multiscale research is to use knowledge of coarser scales of resolution to provide context for interpretation of fine-scale system behavior and to use knowledge of finerscale processes to explain mechanistically the patterns observed at coarser scales (O’Neill et al. 1986).

In this article, we describe examples of LTER research activities at a series of spatial scales; present an example of multiscale, intersite comparison of ecosystem behavior; and describe multiscale research at one LTER site. The LTER program has substantially encouraged comparative analysis across diverse ecosystems. Such intersite research is facilitated through mechanisms such as workshops, scientist exchanges during sabbaticals, and LTER funds used for pilot projects leading to larger intersite studies with separate funding. However, we emphasize that LTER sites were not selected and LTER science was not designed around testing major hypotheses at the intersite level. Further, many of the studies described here are not unique to LTER.

\section{Scales of LTER Research}

Research in the LTER Program occurs at a series of spatial scales: plot/ patch, landscape, region, continent, and globe, but the research focuses primarily on the plot/patch and landscape scales (Figure 1). Past ecological research has tended to focus on the spatial scales at the finer end of the spectrum, whereas global-change programs emphasize very-large-scale phenomena. LTER can help bridge this disparity of scales of study. 
Plot/patch scale. Distinctions among plots, patches, and landscapes as identified here are not necessarily based on absolute size, but, instead, represent the degree of contrast and extent of interaction with neighboring areas. A plot or patch is an ecological or geomorphic unit that can be treated as homogeneous for a particular purpose. Plots generally reside within larger areas of similar makeup-a patch. Patches have edges that border adjacent areas with differing system properties, and patches can be defined within or between systems as diverse as forests, streams, and lakes. Questions concerning edge effects may be included in the study of patches, but plots are usually designed to avoid edge effects.

Much LTER research is designed and implemented at the plot scale, employing experimental manipulations and long-term observations of change in natural systems. The size of these plots ranges from less than one square meter to experimental watersheds of more than 100 ha. Manipulations of plots and patches have targeted nutrient and water availability (e.g., at the Cedar Creek [Minnesota] site) and disturbance, including fire (Konza [Kansas] and Cedar Creek sites), erosion/deposition (Andrews [Oregon] site), clearcut logging (Hubbard Brook [New Hampshire], Coweeta [North Carolina], and Andrews sites), grazing by large mammals (Konza site), cattle fecal pats (Central Plains Experimental Range [Colorado] site), and invasion by exotic organisms (North Temperate Lakes [Wisconsin] and Central Plains Experimental Range sites) (Franklin et al. page 509 this issue).

Landscape scale. Landscapes contain multiple patches, and landscape research concerns interactions among patches (Forman and Godron 1986, Turner 1989, Urban et al. 1987). A small watershed may be treated as a plot in terms of overall water and nutrient balances, but it is a landscape in terms of movement of materials among areas within it.

Many aspects of the landscape scale of LTER work focus on flows of materials (water, nutrients, soil, and sediment organisms) and distributions of plants, animals, soil types, and hydrologic conditions along flow

\section{SPACE SCALES}

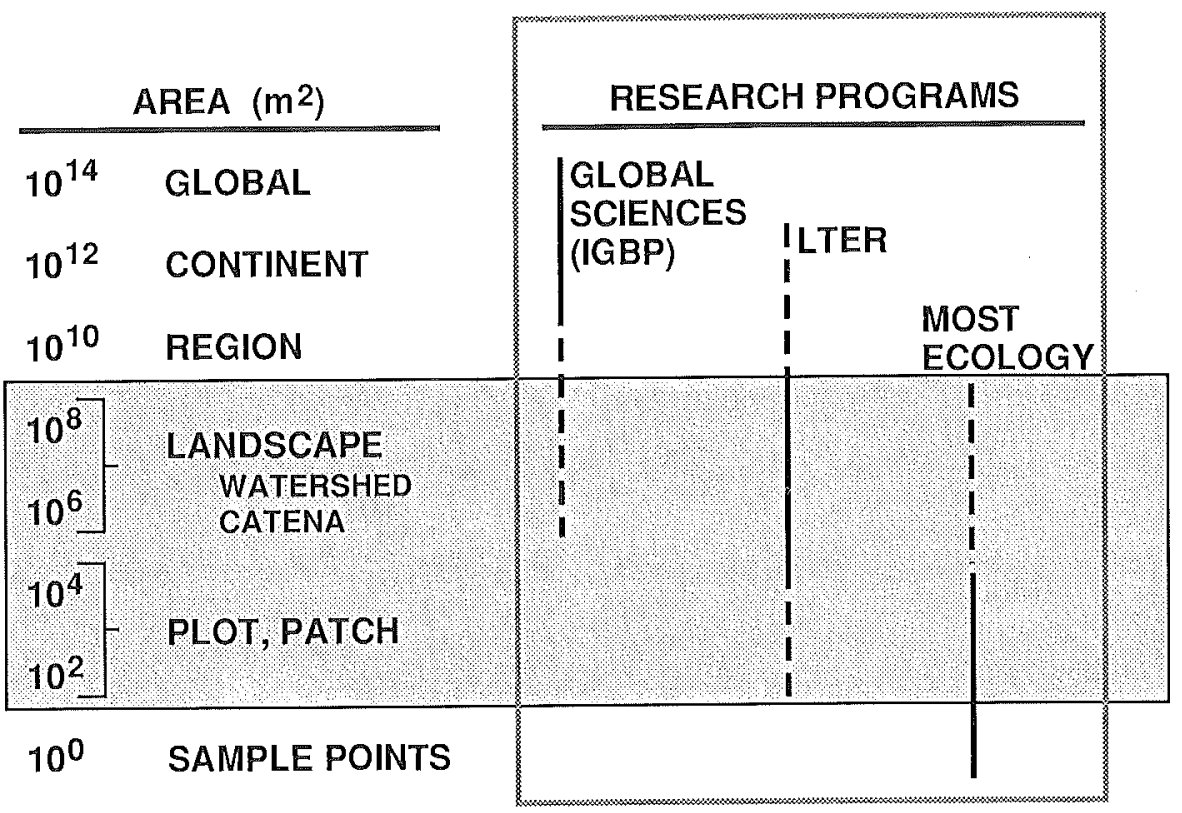

Figure 1. Spatial scales of ecology research. Shading shows scales of LTER concentration.

paths crossing landscapes. At the North Temperate Lakes and Niwot (Colorado) sites, the hydrological flow paths of interest pass through chains of lakes and interspersed areas of subsurface flow (Swanson et al. 1988). The flow paths of materials considered in landscape research at North Inlet (South Carolina) pass from forest through freshwater stream to salt

marsh, estuary, and eventually to the ocean. A landscape perspective is also applied in analysis of flows of sediment through experimental drainage basins at the Niwot and Andrews sites (Caine and Swanson 1989).

A common approach to analysis of landscapes is to scale up to landscapes from plot-level observations sampled along gravitationally determined flow

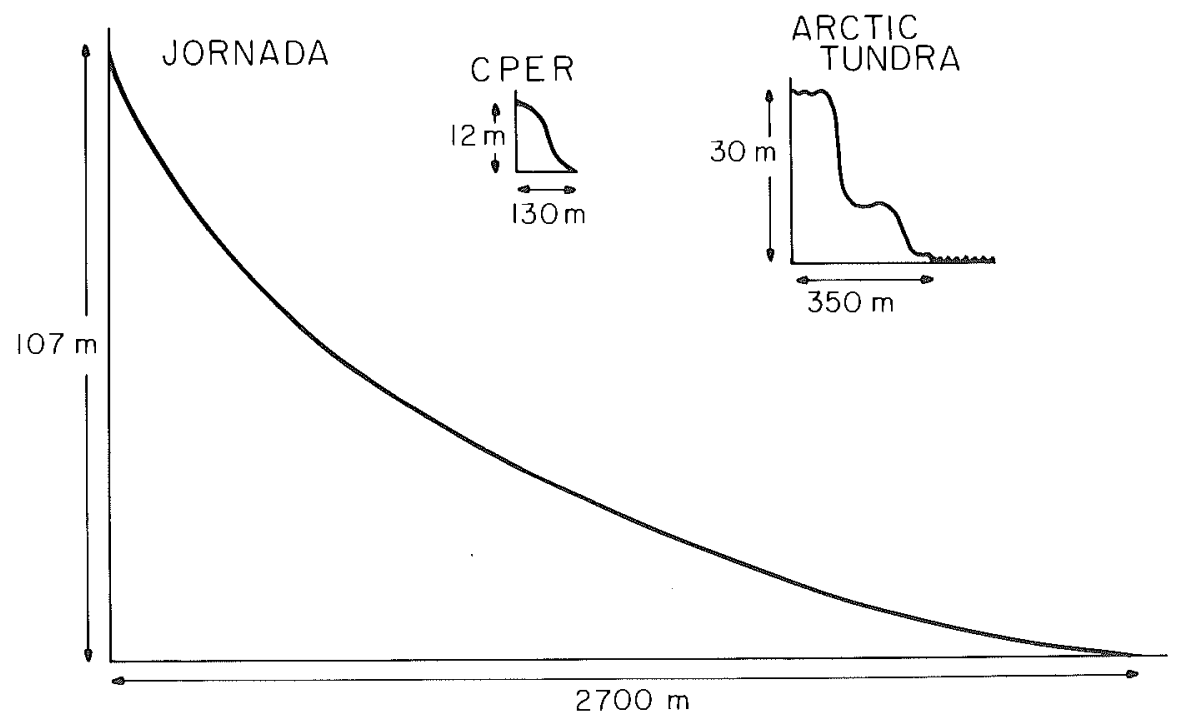

Figure 2. Hillslope cross sections showing topographic profile of sites of soil catena/ connected ecosystem studies at three LTER sites. The length of $1 \mathrm{~m}$ on the vertical axis is 15 times that on the corresponding horizontal axes. CPER: Central Plains Experimental Range. 
paths passing downslope from ridge top to valley floor through a sequence of soil and vegetation patches. This approach is employed in nutrient cycling, vegetation, and soil catena studies, for example, at Central Plains Experimental Range, Jornada (New Mexico), and Arctic Tundra (Alaska) (Figure 2). The types and degrees of control of landscape position on ecosystem properties varies significantly among these sites.

In the arid Jornada environment, for example, productivity of a site is controlled in part by water availability; therefore, patterns of surface water runon/runoff in response to downslope variation in soil hydrologic properties are critical (Whitford et al. 1987, Wondzell et al. 1987). The brief, infrequent runoff events characteristic of the Jornada landscape create patterns of net removal or accumulation of organic matter and nutrients along a topographic sequence-patterns controlled by physical processes.

In contrast, at the Arctic Tundra site, subsurface water flow in a thin (20-100-centimeters-thick) layer above the permafrost transports nutrients downslope during a three-month thaw period each year. Because this flow is subsurface and persists through the growing season, biotic processesfor example, nutrient uptake by plants-control net nutrient retention or loss in sites distributed along the slope (Shaver et al. in press). In both the desert and tundra examples, the interactions of topography, soil properties, and downslope transport processes control patterns of vegetation and rates of biogeochemical processes, although the primary controlling factors differ substantially between systems.

In addition to this approach of viewing landscapes as linear sequences of system elements, it is important to recognize the three-dimensional structure of landscapes. This structure is conspicuous in analysis of landform effects on disturbances. Retrospective studies of the pattern of disturbance across landscapes at LTER sites and elsewhere consider the roles of landforms in constraining disturbance by hurricanes (Harvard Forest [Massachusetts] and Luquillo [Puerto Rico] sites), landslides (Luquillo and Andrews sites), wildfire
(Andrews site), and river channel change (Andrews and Bonanza Creek [Alaska] sites). A common theme in many of these studies is that spatial patterns of disturbances are strongly controlled by landforms; for example, particular topographic settings experience highest hurricane damage (Foster 1988), slopes of 32-38 steepness experience greatest landslide occurrence (Guariguata 1989, Swanson and Dyrness 1975), and areas of wide valley floor have most extensive channel change.

Regional scale. LTER programs are synthesizing regional data sets collected by remote sensing or by field observation at plots. These programs are hubs of region and biome scale studies, including work on the effects of broad-scale disturbances, such as drought and air pollution.

The regional modeling effort of the Central Plains Experimental Range LTER, for example, draws on data from more than 6000 field plots scattered across the central US grasslands from Canada to Mexico, including two other LTER sites (Parton et al. 1987). In another regional study, the Andrews LTER and allied programs have established a network of 0.25 to one-hectare reference stands and other permanent sample plots in the coniferous forests of western North America. Some plots date from as early as 1915, although most began in the 1970s. Long-term records from these plots, which are located within forests ranging from 10 to 1000 years since originating disturbance, are used in studies of forest succession and demography and in modeling effects of land use and climate change on forests of the region (e.g., Franklin and DeBell 1988, Harmon et al. 1990). ${ }^{1}$

Dynamics of boundaries (ecotones) between biomes are another aspect of region-scale ecosystem research. The Sevilleta (New Mexico) LTER site, for example, contains transitions among four biomes, providing an opportunity to examine the effects of climate change on the spatial distribution of ecosystems at various tempo-

${ }^{1}$ F. J. Swanson, S. Wondzell, and G. E. Grant, 1990, manuscript submitted.

${ }^{2}$ V. H. Dale and J. F. Franklin, 1990, manuscript submitted. ral scales, for example, El Niño and potential climate change during the next century (Gosz and Sharpe 1989). Scientists at other sites are studying the dynamics of snow-tundra (Arctic Tundra and Niwot sites), foresttundra (Niwot site), and marineterrestrial (North Inlet site) interfaces. Sampling approaches include longterm observations of the physical environment (e.g., seasonal snow duration), soil properties, vegetation, and small-mammal populations along belt transects and series of plots crossing ecotones. It is hypothesized that these ecotonal sites will be among the first to display biogeographic aspects of ecosystem response to climate and land-use change.

Continental scale. Continent-spanning comparative research is greatly facilitated by the network of LTER sites extending over 11 biomes-from the north slope of Alaska south to Puerto Rico and from Oregon east to New England. Currently, subsets of LTER sites are undertaking comparative and cooperative field studies on subjects such as effects of resource limitations on productivity and plant succession, processes and rates of wood decomposition, and invading species and their ecological effects. Sites for some studies, such as the resource limitations project, are selected to represent points along a physiognomic gradient from shortgrass to forests.

The most extensive example of intersite research is a 21-site (all the LTER sites plus four additional sites) study of leaf litter decomposition. This study offers a first-of-its-kind opportunity to distinguish effects of litter chemistry and climate on decomposition rates across such a broad range of environments. Also at the continental scale, some LTER sites and research groups are contributing to research programs addressing the effects of climate change and broadscale air pollution on forest and freshwater ecosystems of North America (e.g., Hubbard Brook, North Temperate Lakes, and Harvard Forest).

Global scale. LTER involvement in global-scale issues is in its initial stages. LTER is providing field observations and experimentation for verification of remote sensing and model- 
ing efforts that are part of the National Science Foundation's Global Geoscience Programs. To global change research programs, LTER brings experienced, interdisciplinary teams of ecosystem scientists, long-term data sets on environmental and biological conditions, and facilities and logistical support for field studies. The First ISLSCP (International Landsurface Climatology Project) Field Experiment (FIFE) project at the Konza LTER site is a prime example of an effort to couple ground-based and remotely sensed information sampled at a series of spatial scales of resolution (see Franklin et al. 1990 for a brief description).

Current interactions with scientific groups in other countries, notably in Europe, China, and South America, are an early step in expanding largescale research to an international network of cooperating research sites and programs. This research has been facilitated in part by links among biosphere reserves in UNESCO's Man and the Biosphere Program, of which several LTER sites are a part.

\section{Intersite comparison}

Intersite comparisons reveal the importance of conducting multiscale analysis of ecosystems and of distinguishing system features controlled by absolute and relative (within-site) scales. The variable size and the network structure of riverine systems provide useful examples for multiscale comparison. Unfortunately, no LTER site contains the full continuum from small streams to large rivers, so we cannot deal comprehensively with the issue of scaling up through a drainage network. However, we can compare two study areas in different locations within their respective river networks and identify similarities and differences in system properties. The role of LTER within this analysis is to foster such comparisons; LTER sites were not selected originally to test these ideas.

Considering interactions of rivers and their riparian forests, we see important effects of scale in comparing large, floodplain rivers (LTER-funded research from 1982 to 1989 in the Illinois-Mississippi Rivers [Illinois] site) and small, mountain streams (Andrews site) (Figures 3 and 4).

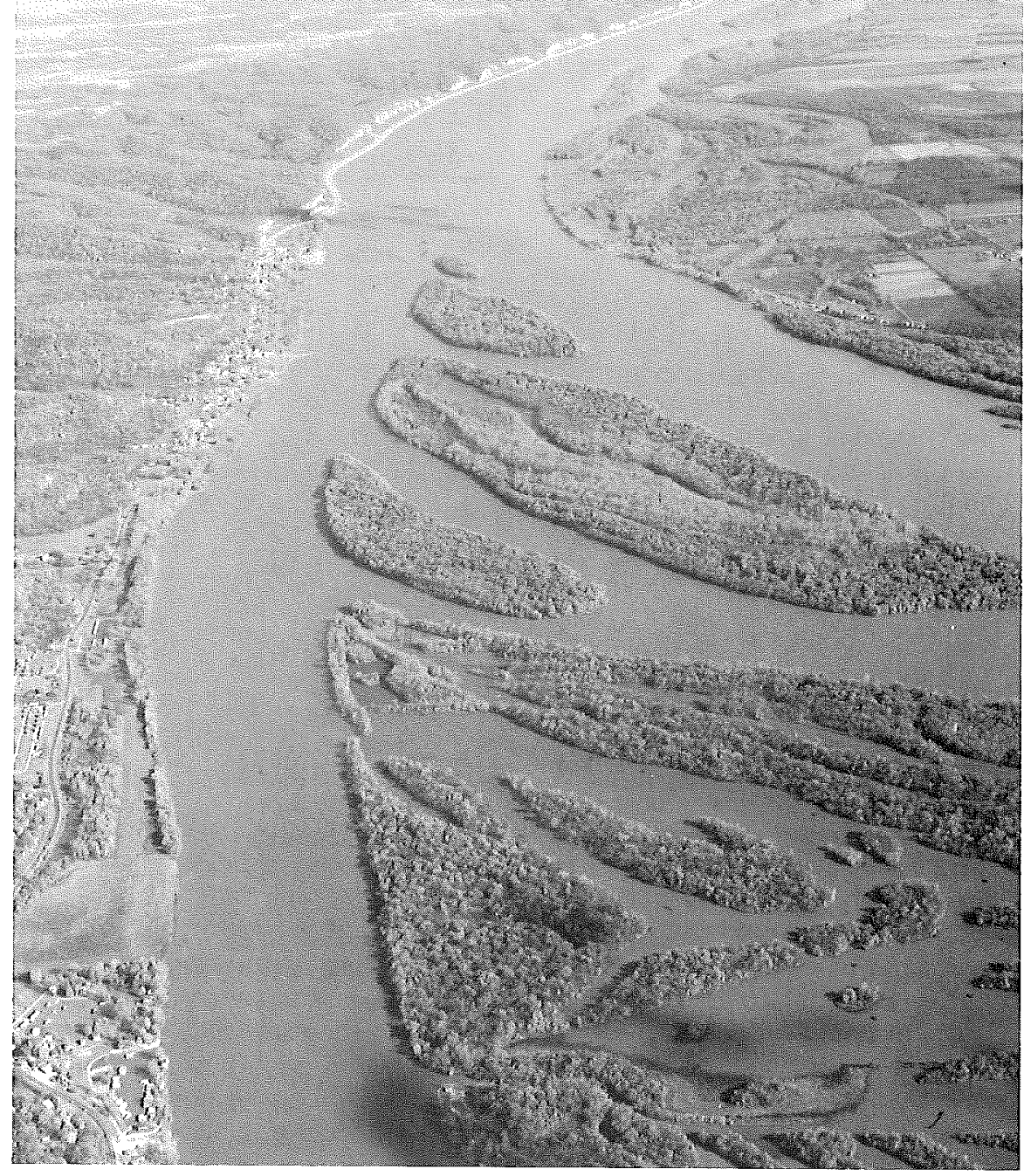

Figure 3. Confluence of the Mississippi and Illinois Rivers $64 \mathrm{~km}$ upstream of St. Louis, Missouri, showing the floodplain forest, side channels, and backwaters typical of both channels.

These systems have striking similarities in ecosystem function. In both systems, streamside forests regulate riverine habitat structure (downed logs at any flow stage and standing trees during floods) and nutrient availability (input of litter and nutrients dissolved in groundwater to the aquatic system; Grubaugh and Anderson 1989, Sedell et al. 1989). These two systems differ greatly in absolute scales of channel and floodplain width, channel gradient, average annual and peak flows, and duration, predictability, and areal extent of inundation of floodplain forest (Table 1). The physical differences between sites result in substantial differences in the location and timing of river-forest interactions and in the resulting conceptual models of system behavior.

A key to contrasting these two flu- vial systems is the flood regime. Floods in large, temperate, lowland rivers tend to be predictable in seasonality. Large drainage areas, low gradient of the main channel, and low water velocity through forest vegetation and complex channels result in slow passage of large-volume floods, so that extensive areas of floodplain forests may be inundated many months each year where landforms permit. Consequently, many organisms, including fish, have adapted to using the flooded floodplain environment in various life-history stages. Overall, aquatic productivity is high where river systems exchange nutrients with highly productive terrestrial systems on periodically flooded floodplain areas.

In steep, mountain channels, on the other hand, flooding by rainfall and rain-on-snow events is likely to be less 


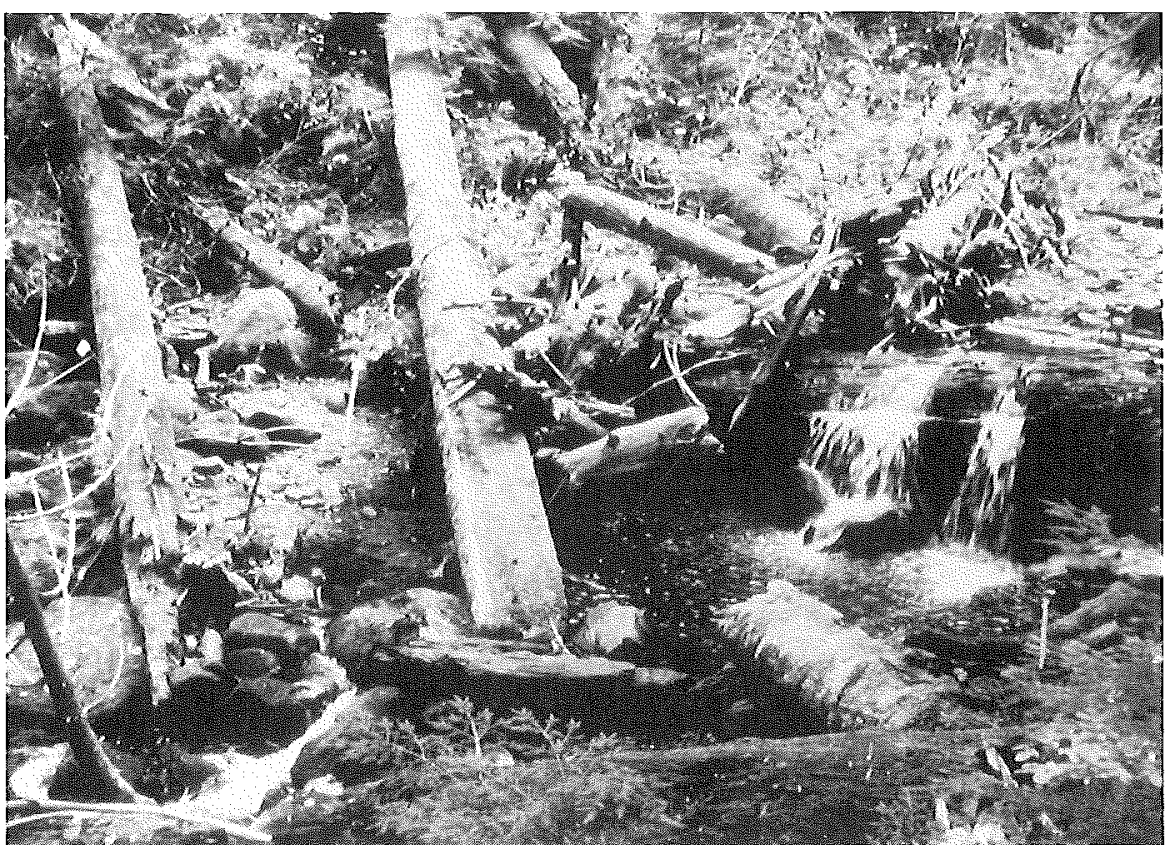

Figure 4. Mountain streams in the Lookout Creek basin (Andrews [Oregon] site) with narrow floodplain and abundant woody debris from streamside forest.

predictable in timing and inundates much less floodplain area for shorter periods of time (Table 1). Basins with a seasonal snowmelt hydrograph, however, may be quite predictable in timing of high flows (Resh et al. 1988). The steep channels and small drainage area facilitate rapid passage of flood flows, which have smaller total volumes than floods produced in much larger basins. Furthermore, in nonglaciated areas, valley floors and their floodplains tend to be narrow, because of constraints such as bedrock outcrops and landslides from adjacent hillslopes. Aquatic organisms in these systems possess few, if any, adaptations to the flooded flood- plain environment. Aquatic productivity appears to be regulated by upstream processes that control the quantity and quality of nutrients and water delivered to a downstream site and by effects of adjacent forest on the channel environment (e.g., shading and input of coarse, woody debris).

A major difference between the two systems, therefore, is that river-forest interactions are played out predominantly in the flooded floodplain environment of the large, lowland river and in the channel of the steep, mountain river. Actually, both of these study sites and much of the world's river systems contain a mixture of

Table 1. Characteristics of a big, floodplain river (Illinois-Mississippi River LTER Site) and a small, mountain stream (Lookout Creek, Andrews [Oregon] LTER Site).

\begin{tabular}{lcc}
\hline $\begin{array}{l}\text { Hydrologic and average } \\
\text { characteristics }\end{array}$ & $\begin{array}{c}\text { Mississippi } \\
\text { River near } \\
\text { Burlington, IA }\end{array}$ & $\begin{array}{c}\text { Lookout } \\
\text { Creek, OR }\end{array}$ \\
\hline Channel width $(\mathrm{m})$ & $600^{*}$ & $10-12$ \\
Floodplain width $(\mathrm{m})$ & $3400^{*}$ & $6-8$ \\
Channel gradient $(\mathrm{m} / \mathrm{m})$ & $0.0007^{\dagger}$ & 0.022 \\
$\begin{array}{l}\text { Discharge }\left(\mathrm{m}^{3} / \mathrm{s}\right) \\
\quad \begin{array}{l}\text { Average annual flow } \\
\text { Peak flow }\end{array}\end{array}$ & $1815^{*}$ & 3.6 \\
$\begin{array}{l}\text { Flood (inundation of } \\
\text { floodplain forest) } \\
\text { duration (days/yr) }\end{array}$ & $5044^{\ddagger}$ & 49 \\
\hline
\end{tabular}

${ }^{*}$ Grubaugh and Anderson (1988).

tFremling et al. (1989).

†Stahl et al. (1989) at Keokuk, IA, 1878-1988. these two contrasting cases. Geologic and human-constructed constraints on water flow and valley floor geomorphology cause great along-stream variation in the degree and type of river-forest interaction.

We recognize this variation as we shift our view from the valley floor cross-section (plot scale) up to a scale that includes longitudinal variation in valley floor structure and its role in regulating river-forest interaction (landscape scale). In the case of the small mountain river at the Andrews site, landslides, bedrock, and alluvial fans locally constrain floodplain width and, therefore, the opportunity for river-forest interaction. Areas upstream of constrained valley-floor segments tend to have extensive riverforest interaction (Figure 5).

In the Illinois-Mississippi River systems, navigation dams and levees for flood protection (Figure 5) are major constraints on valley floor processes. Areas upstream of the dams are inundated on a continuous basis, and levee districts are isolated from all but the major floods (occurring every 2550 years), thereby eliminating the flood pulse effect (periodic inundation of floodplain areas). After many decades, the impounded areas will accumulate sufficient sediment that emergent bars and islands form and become forested (Bhowmik et al. 1986), so the flood pulse phenomenon is reestablished.

A common theme at these two sites is that aquatic productivity is highest where river-forest interaction is greatest. Aquatic productivity at a site reflects a tangled web of interactions among physical and biological processes at several absolute and relative spatial scales and at several time scales. Processes related to differences in absolute spatial scales between the two sites contribute to longer-duration flooding in the larger basin. Both systems provide examples of landform (including dams) constraints on the extent of river-forest interaction. Important temporal dimensions of river-forest interactions include seasonal patterns of hydrology and production/decomposition of organic detritus and the decades-to-millennia scale of geomorphic change.

The types of contrasts represented by these mountain stream and big, lowland river examples have resulted 
in a pair of theories of riverine ecosystems behavior. These theories differ in the scale and processes emphasized. The flood pulse concept of river-forest interaction (Junk et al. 1989, Welcomme 1979) states that seasonal flood-flows onto floodplains strongly and positively influence the productivity of the fluvial system. This conceptual model derives from analysis of large, lowland rivers at the scale of a valley floor cross-section or individual reach of river. The river continuum concept of river ecosystems (Minshall et al. 1985, Vannote et al. 1980) emphasizes controls of upstream factors, rather than lateral floodplain systems, on properties of stream ecosystems. This concept considers the full length of the drainage system, which typically encompasses a landscape or even an entire region.

Attention to landscape and fulldrainage basin scales of variation in system structure and function reveals that a marriage of flood pulse and river continuum concepts is probably required to explain river-forest interactions in most river systems (Sedell et al. 1989). The flood pulse concept accounts for lateral influences within a reach, and the river continuum concept offers a framework for interpretation of links among successive reaches along the stream.

\section{Multi-scale LTER studies- future work}

Research programs at several LTER sites are tackling the important, but difficult, task of working across multiple spatial scales. The Sevilleta LTER group, for example, is using Fourier transform infrared spectroscopy (FTIR) to sample trace gas concentrations over terrestrial and aquatic ecosystems at scales ranging from meters to a kilometer (Gosz et al. 1988). This new technology is being used to measure spatial heterogeneity of biogeochemical processes at a range of scales in both homogeneous vegetation and across ecotones. At fine scales, the spatial patterns of biogeochemical processes are known to be extremely variable (Robertson et al. 1988). The purpose of the multiscale work with FTIR is to better characterize the spatial patterns of variation so that future measurements can be scaled appropriately: observations at
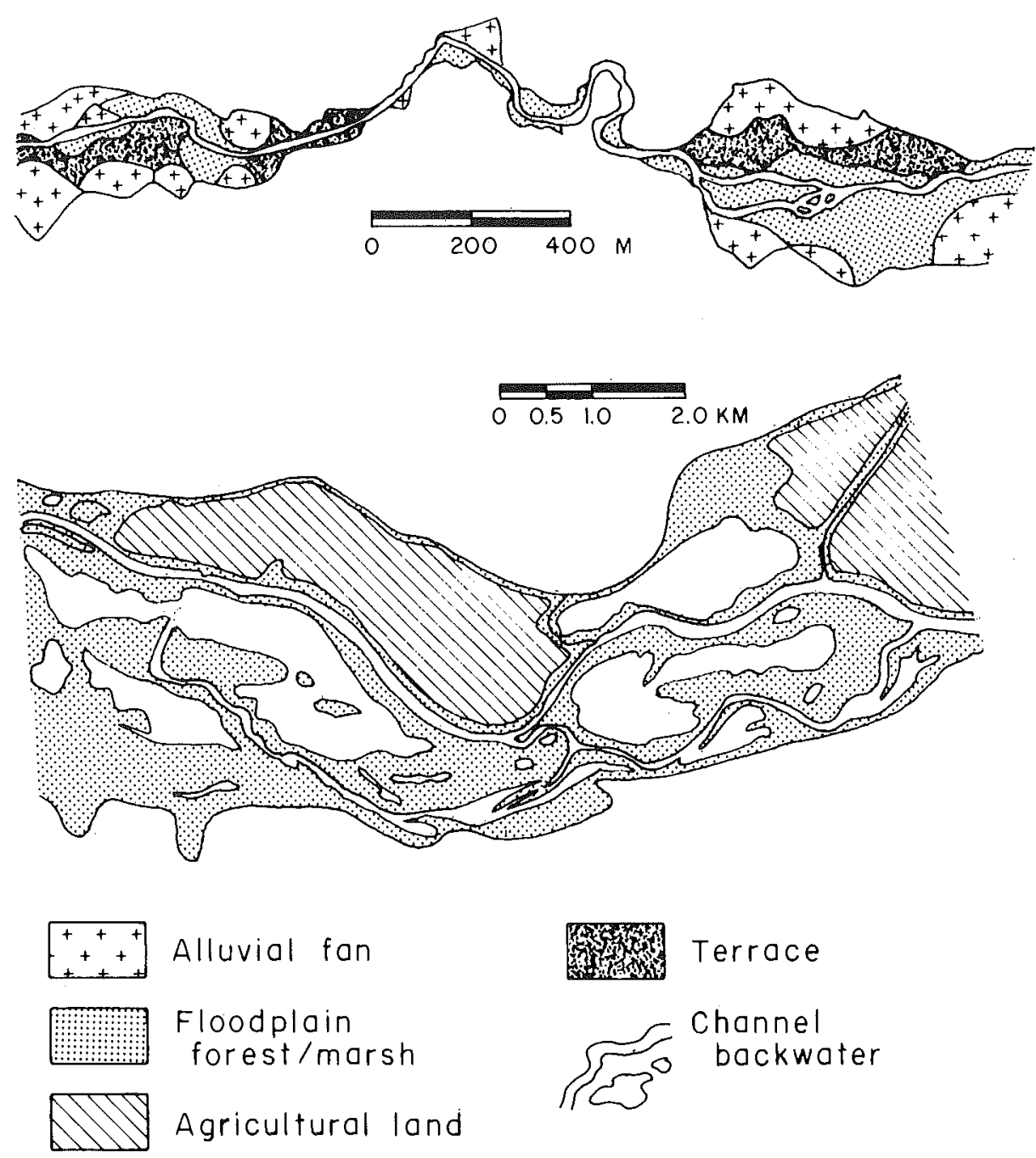

Alluvial fan

Floodplain
forest/marsh

Agricultural land
Terrace

Channel

backwater

Figure 5. Map of reaches of Lookout Creek (top) and Illinois River (bottom) valley floors. The Lookout Creek site shows substantial variation in the width of its valley floor as a result of geological processes operating on the valley walls. The Illinois River site $(160 \mathrm{~km}$ upstream of confluence with the Mississippi River) has a more uniform valley floor width. Flow is from right to left.

finer scales may be directed to interpretation of controls on process rates, whereas coarser-scale observations can average out fine-scale variation to yield useful measures of flux between landscapes and the atmosphere.

Another multiscale project in the desert environment of Sevilleta measures streamflow in a nested set of 20 to 350,000 -hectare drainage basins to sense climatic processes at a variety of temporal and spatial scales. Hypotheses concerning scale dependence of the streamflow regime include:

- Small basins with dimensions smaller than single convective storm cells experience several flow events per year.
- Intermediate-sized basins $(200$ ha) that are larger than the typical precipitation cell diameter experience less frequent, but more destructive, flow events, because unusually large cell's or closely spaced cells are needed to produce a discharge event.

- Large basins exhibit spatially intermittent flow; some reaches have perennial flow, and others carry surface flow periodically. - Long-term gauging records on the Gila $(484,000$-hectare basin area sampled) and $P e c o s(49,000$ hectare area sampled) rivers indicate that the magnitude of annual flows differs by a factor of 6.0 to 7.4 between El Niño and La Niña 
years (Molles and Dahm in press).

As these spatial and temporal patterns of streamflow become better known, they will form an important framework for analysis of geomorphic and ecological change of stream and riparian systems of the Sevilleta.

These analytical approaches are mainly descriptive and exploratory at present. But they set the stage to test scale theory relating to ecosystem processes (O'Neill et al. 1986), to detect effects of climate and other environmental change, and to design better field measurement systems for sampling at appropriate scales.

\section{Conclusions}

The importance of tackling ecological questions at their appropriate scales with appropriate tools is widely recognized (Delcourt et al. 1983, Gosz and Sharpe 1989, O'Neill et al. 1986). In many cases, it is important to examine ecosystems at different spatial scales. By extending the breadth of temporal scales considered in a sustained research program, LTER has also made it possible, indeed essential, to examine ecosystem behavior on multiple spatial scales.

\section{Acknowledgments}

This work was supported by National Science Foundation grants BSR 8514325 and BSR 8508356 to Andrews LTER and BSR 8114563 and BSR 8612107 to the Illinois-Mississippi River LTER and by a loan of equipment from the Upper Mississippi River Basin Association. C. Dahm, S. Wondzell, J. Franklin, and J. Magnuson contributed valuable insights during preparation of this article.

\section{References cited}

Bhowmik, N. G., J. R. Adams, and R. E. Sparks. 1986. Fate of a navigation pool on the Mississippi River. Journal of Hydraulic Engineering 112: 967-970.

Caine, N., and F. J. Swanson. 1989. Geomorphic coupling of hillslopes and channel systems in two small mountain basins. Zeitschrift fur Geomorphologie 33: 189-203.

Callahan, J. T. 1984. Long-term ecological research. BioScience 34: 363-367.

Delcourt, H. R., P. A. Delcourt, and T. Webb III. 1983. Dynamic plant ecology: the spectrum of vegetation change in time and space.
Quaternary Science Reviews 1: 153-175.

Formann, R. T. T., and M. Godron. 1986. Landscape Ecology. John Wiley \& Sons, New York.

Foster, D. R. 1988, Species and stand response to catastrophic wind in central New England, U.S.A. J. Ecol. 76: 135-151.

Franklin, J. F., C. S. Bledsoe, and J. T. Callahan. 1990. Contributions of the Long-Term Ecological Research Program. BioScience 40: 509-523.

Franklin, J. F., and D. S. DeBell. 1988. Thirtysix years of tree population change in an old-growth Pseudotsuga-Tsuga forest. Can. J. For, Res. 18: 633-639.

Fremling, C. R., J. L. Rasmussen, R. E. Sparks, S. P. Cobb, C. F. Bryan, and T. O. Claflin. 1989. Mississippi River fisheries: a case history. Pages 309-351 in D. P. Dodge, ed. Proceedings of the International Large River Symposium (LARS). Canadian Special Pub lication in Fisheries and Aquatic Science 106, Ottawa, ON.

Gosz, J. R., C. N. Dahm, and P. G. Risser 1988. Long-path FTIR measurement of atmospheric trace gas concentrations. Ecology 69: $1326-1330$.

Gosz, J. R., and P. J. H. Sharpe. 1989. Broad scale concepts for interaction of climate, topography, and biota at biome transitions. Landscape Ecology 3: 229-243.

Grubaugh, J. W., and R. V. Anderson. 1988. Spatial and temporal variability of floodplain habitat: long-term changes at Pool 19, Mississippi River. Am. Midl. Nat. 119: $402-$ 411.

1989. Upper Mississippi River: seasonal and floodplain influences on organic matter transport. Hydrobiologia 174: 235244.

Guariguata, M. R. 1989. Landslide natural disturbance and forest regeneration in the Luquillo Mountains of Puerto Rico. Masters dissertation, University of Florida, Gainsville.

Harmon, M. E., W. K. Ferrell, and J. F. Franklin. 1990. Effects of carbon storage of conversion of old-growth forests to young forests. Science 247: 699-701.

Junk, W. J., P. B. Bayley, and R. E. Sparks. 1989. The flood pulse concept in riverfloodplain systems. Pages $110-127$ in D. P. Dodge, ed. Proceedings of the International Large River Symposium (LARS). Canadian Special Publication in Fisheries and Aquatic Science 106.

Magnuson, J. J. 1990. Long-term ecological research and the invisible present. BioScience 40: 495-501.

Magnuson, J. J., T. K. Kratz, T. M. Frost, C. J. Bowser, B. J. Benson, and R. Nero. In press. Expanding the temporal and spatial scales of ecological research: examples from the LTER program in the United States. In P. G. Risser and J. Melillo, eds. Long-Term Ecological Research: An International Perspective. John Wiley \& Sons, New York.

Minshall, G. W., K. W. Cummins, R. C. Peterson, C. E. Cushing, D. A. Burns, J. R. Sedell, and R. L. Vannote. 1985. Developments in stream ecosystem theory. Can. J. Fish. Aquat. Sci. 42: 1045-1055.

Molles, M. C., and C. N. Dahm. In press. El Niño and La Niña: a global perspective on stream ecology. J. North Am. Benthol. Soc.
O'Neill, R. V., D. L. DeAngelis, J. B. Waide, and T. F. H. Allen. 1986. A Hierarchial Concept of Ecosystems. Princeton University Press, Princeton, NJ.

Parton, W. J., J. W. B. Stewart, and C. V. Cole. 1987. Dynamics of C, N, P, and S in grassland soils: a model. Biogeochemistry 5: 109131.

Resh, V. H., A. V. Brown, A. P. Covich, M. E. Gurtz, H. W. Li, G. W. Minshall, S. R. Reice, A. L. Sheldon, J. B. Wallace, and R. C. Wissmar. 1988. The role of disturbance in stream ecology. J. North Am. Benthol. Soc. 7: 433-455.

Robertson, G. P., M. A. Huston, F. C. Evans, and J. M. Tiedje. 1988. Spatial variability in a successional plant community: patterns of nitrogen availability. Ecology 69: 15171524.

Sedell, J. R., J. E. Richey, and F. J. Swanson. 1989. The river continuum concept: a basis for the expected ecosystem behavior of very large rivers? Pages 49-55 in D. P. Dodge, ed. Proceedings of the International Large River Symposium (LARS). Canadian Special Publication in Fisheries Aquatic Science 106.

Shaver, G. R., K. J. Nadelhoffer, and A. E. Giblin. In press. Biogeochemical diversity and element transport in a heterogeneous landscape: the North Slope of Alaska. In M. G. Turner and R. H. Gardner, eds. Quantitative Methods in Landscape Ecology. SpringerVerlag, New York.

Stahl, R. L., R. H. Coupe, T. E. Richards, and P. D. Hayes. 1989. Water resources data Illinois water year 1988. vol. 1. Illinois except Illinois River Basin. US Geological Survey Water-Data Report IL-88-1, Urbana, IL. Swanson, F. J., and C. T. Dyrness. 1975. Impact of clear-cutting and road construction on soil erosion by landslides in the western Cascade Range, Oregon. Geology 3: 393396.

Swanson, F. J., and J. F. Franklin. 1988. The Long-Term Ecological Research Program. EOS: Transactions of the American Geophysical Union 69(3): 34, 36, 46.

Swanson, F. J., T. K. Kratz, N. Caine, and R. G. Woodmansee. 1988. Landform effects on ecosystem patterns and processes. BioScience 38: 92-98.

Turner, M. G. 1989. Landscape ecology: the effect of pattern and process. Annu. Rev. Ecol. Syst. 10: 171-197.

Urban, D. L., R. V. O'Neill, and H. H. Shugart Jr. 1987. Landscape ecology, BioScience 37: 119-127.

Vannote, R. L., G. W. Minshall, K. W. Cummins, J. R. Sedell, and C. E. Cushing. 1980. The river continuum concept. Can. J. Fish. Aquat. Sci. 37: 130-137.

Welcomme, R. 1979. Fisheries Ecology of Floodplain Rivers. Longman, London.

Whitford, W. G., J. F. Reynolds, and G. L. Cunningham. 1987. How desertification affects nitrogen limitation of primary production on Chihuahuan Desert watersheds. USDA Forest Service General Technical Report RM-150, Fort Collins, CO.

Wondzell, S. M., G. L. Cunningham, and D. Bachelet. 1987. A hierarchical classification of landscapes: some implications for understanding local and regional vegetation $\mathrm{dy}$ namics. USDA Forest Service General Technical Report RM-150, Fort Collins, CO. 